\title{
PENATAAN HUBUNGAN HUKUM DALAM PENGUASAAN, PEMILIKAN, PENGGUNAAN, DAN PEMANFAATAN SUMBER DAYA AGRARIA (Studi Awal terhadap Konsep Hak Atas Tanah dan Ijin Usaha Pertambangan) Oloan Sitorus ${ }^{1}$
}

\begin{abstract}
The legal relations of land tenure, ownership, usage and utilization of agrarian resources still require further restructurization. The economic development during the New Order era abandoned the necessity of the legal differences of land tenure and land ownership, with the legal relations of the collection and utilization of agrarian resources excluding land. ConseQuently, there are misleading in interpreting the right and permission as a form of legal relationship. These misleading should be rectified in the land law draft which will be drafted. The future land law should be able to clearly regulate the legal relations of land tenure, and should be consistently built since the early tenure in the form of occupation, possession, and ownership by the Ministry of Agrarian and Land Use Planning/NLA. Land tenure relationship is mentioned by the concept of land right. Furthermore, it should be confirmed in the Land Law Draft that the relationship between collection and utilization of natural resources are confirmed as permit, and should not be considered as the basic of land utilization as earth surface. Reclamation set up by the concession holders for mining area recovery should not be considered as an "entry point" to legalize land rights.

Keywords: legal relation, right, license

Intisari: Hubungan hukum penguasaan dan pemilikan serta penggunaan dan pemanfaatan Sumberdaya Agraria masih memerlukan penataan. Perkembangan ekonomi selama era Orde Baru mengabaikan pentingnya pembedaan hubungan hukum tenurial penguasaan dan pemilikan tanah dengan hubungan hukum pengambilan dan pemanfaatan sumberdaya agraria selain tanah. Akibatnya, terjadi kesesatan berfikir dalam mamaknai hak dan ijin sebagai bentuk hubungan hukum. Kesesatan berfikir ini harus diakhiri di dalam RUU Pertanahan yang akan disusun. RUU Pertanahan itu harus jelas mengatur bahwa hubungan hukum tenurial dengan tanah harus konsisten dibangun sejak penguasaan awal dalam bentuk okupasi (occupation), penguasaan dan pemunyaaan (possession), dan pemilikan (ownership) oleh Kementerian ATR/BPN. Hubungan tenurial dengan tanah disebut dengan konsep hak atas tanah. Selanjutnya, perlu dikonfirmasi dalam RUU Pertanahan tersebut bahwa hubungan pengambilan dan pemanfaatan kekayaan alam dikonfirmasi sebagai ijin, yang tidak dapat dijadikan sebagai dasar untuk menggunakan tanah sebagai permukaan bumi. Reklamasi yang dilakukan pemegang ijin untuk memulihkan areal tambang, tidak dapat dijadikan sebagai "pintu masuk" bagi terjadinya hak atas tanah.
\end{abstract}

Kata kunci: hubungan hukum, hak atas tanah, ijin

\section{A. Pendahuluan}

Diskursus mengenai penataan hubungan hukum dalam penguasaan dan pemilikan tanah penting dilakukan saat ini, ketika konsep antara hak atas tanah dan ijin terhadap pemanfaatan sumberdaya agraria disinyalir mengalami berbagai dinamika. Penulis berasumsi bahwa berbagai

\footnotetext{
r Ketua Sekolah Tinggi Pertanahan Nasional, Yogyakarta.E-mail: stpn.oloan@gmail.com
} Diterima: 15 Maret 2016

Direview: 24 Maret 2016

perubahan yang terdapat dalam praktik pelaksanaan konsep hukum hak atas tanah dan ijin terhadap pemanfaatan sumberdaya agraria tidak luput dari perubahan yang terjadi pula dalam hubungan negara terhadap tanah dan sumberdaya agraria lainnya.

Hubungan hukum dengan tanah dan sumberdaya agraria lainnya diatur dalam konstitusi Negara dan berbagai aturan mengenai pertanahan/ agraria, yang intinya menyatakan bahwa semua 
sumberdaya agraria dikuasai oleh negara dan dipergunakan untuk sebesar-besar kemakmuran rakyat (Pasal 33 ayat (3) UUD 1945). Pengertian 'dikuasai oleh negara' dimaknai sebagai kewenangan publik, yang berarti bahwa 'Hak Menguasai Negara' (HMN) sebagai bentuk hubungan hukum antara negara dengan sumberdaya agraria adalah hubungan yang bersifat publik, bukan privat sebagaimana hubungan negara dengan sumberdaya agraria pada pemerintahan kolonial dan pemerintahan feodal sebelumnya.

Hubungan yang bersifat publik tersebut secara jelas dijabarkan dalam Pasal 2 ayat (2) UUPA yang menyatakan bahwa HMN memberi wewenang untuk: pertama, mengatur dan menyelenggarakan peruntukan, penggunaan, persediaan dan pemeliharaan bumi, air dan ruang angkasa tersebut; kedua, menentukan dan mengatur hubungan-hubungan hukum antara orang-orang dengan bumi, air dan ruang angkasa; ketiga, menentukan dan mengatur hubungan-hubungan hukum antara orang-orang dan perbuatan-perbuatan hukum yang mengenai bumi, air dan ruang angkasa. Dalam perkembangan selanjutnya, pasca reformasi, Mahkamah Konstitusi R.I. (MK RI), juga berkontribusi menjelaskan makna HMN. Dalam berbagai putusannya, MK RI menegaskan bahwa HMN berisi kewenangan untuk: (a) merumuskan kebijakan (beleid); (b) melakukan pengaturan (regelendaad) dalam hal ini kewenangan legislasi (DPR + Pemerintah) dan regulasi (Pemerintah); (c) melakukan pengurusan (bestuursdaad), seperti: pemberian dan pencabutan izin, konsesi, dan lisensi; (d) melakukan pengelolaan (beheersdaad) melalui mekanisme pemilikan saham atau keterlibatan langsung BUMN/D; dan (e) melakukan pengawasan (toezichthoundendaad): oleh Pemerintah dalam rangka pengendalian. Dalam tafsir penulis, hubungan hukum yang lain, seperti dalam bentuk 'hak atas tanah' merupakan bagian dari isi kewenangan melakukan pengurusan (bestuursdaad). Dengan demikian, penentuan hubungan hukum dengan tanah dalam bentuk hak atas tanah dan ijin terhadap pemanfaatan sumberdaya agraria lainnya (termasuk konsesi dan lisensi) merupakan salah satu isi dari kewenangan HMN di bidang sumberdaya agraria.

\section{B. Hak atas tanah sebagai hubungan tenurial}

Hubungan antara orang/badan hukum dengan tanah diakomodasi dengan 'hak', yang kemudian disebut hak atas tanah seperti dinyatakan dalam Pasal 4 jo Pasal 16 UUPA. Kewenangan yang terdapat dalam hak atas tanah bersifat privat, seperti: menggunakan, mengalihkan (memindahkan, menyerahkan/melepaskan), dan menjadikan sebagai agunan.

Dalam konteks Hukum Perdata, kekuatan hubungan hukum hak atas tanah dibedakan atas hak kebendaan dan hak perorangan. Hak Kebendaan (zakelijke recht) memiliki kekuatan hukum yang lebih kuat dibandingkan dengan hak perorangan (personlijk recht). Hak Kebendaan yang melekat pada bendanya dapat dipertahankan kepada siapa pun, sedangkan Hak Perorangan hanya dapat dipertahankan pada orang tertentu (Djuhaendah Hasan 1996, 115). Secara sederhana kekuatan hubungan hukumnya dapat dibandingkan seperti dalam ragaan berikut ini.

Tabel 1. Kriteria Hak Kebendaan dan Hak Perorangan Unsur Hak Kebendaan Hak Perorangan

\begin{tabular}{|c|c|c|}
\hline Unsur & Hak Kebendaan & Hak Perorangan \\
\hline $\begin{array}{l}\text { Sifat } \\
\text { hubungan }\end{array}$ & $\begin{array}{l}\text { Ada hubungan hukum langsung antara } \\
\text { subjek dan objek berupa hubungan } \\
\text { kepemilikan/ kepunyaan }\end{array}$ & $\begin{array}{l}\text { Tidak ada hubungan } \\
\text { kepemilikan / kepunyaan yang } \\
\text { ada hanya hubungan hukum } \\
\text { antar subjek berkenaan dengan } \\
\text { objek }\end{array}$ \\
\hline \multirow[t]{2}{*}{$\begin{array}{l}\text { Isi } \\
\text { kewenangan }\end{array}$} & $\begin{array}{l}\text { Memberikan kewenangan yang luas yaitu } \\
\text { memanfaatkan / menikmati benda/objek } \\
\text { yang bersangkutan atau hasilnya, } \\
\text { melakukan semua perbuatan hukum atas } \\
\text { benda, dan memanfaatkan nilai ekonomis } \\
\text { benda }\end{array}$ & $\begin{array}{l}\text { Hanya memberi kewenangan } \\
\text { terbatas yaitu memanfaatkan/ } \\
\text { menikmati benda/hasilnya }\end{array}$ \\
\hline & $\begin{array}{l}\text { Haknya melekat/mengikuti terus menerus } \\
\text { di tangan siapapun benda berada (droit de } \\
\text { suite) }\end{array}$ & $\begin{array}{l}\text { Hak hanya melekat selama } \\
\text { berada dalam penguasaan subjek } \\
\text { yang diberi }\end{array}$ \\
\hline $\begin{array}{l}\text { Pembebana } \\
\text { n dengan } \\
\text { hak lain }\end{array}$ & $\begin{array}{l}\text { Dapat dibebani dengan hak lain baik hak } \\
\text { perorangan maupun hak kebendaan } \\
\text { lainnya dan hak jaminan untuk pelunasan } \\
\text { utang }\end{array}$ & $\begin{array}{l}\text { Tidak dapat dibebani dengan } \\
\text { hak yang lain apapun. }\end{array}$ \\
\hline
\end{tabular}

Sumber: Diringkas dari L.J. van Apeldoorn dan Sri Soedewi Masjchoen Sofwan

Dalam konteks UUPA, hubungan hukum dengan tanah yang disebut sebagai hak atas tanah adalah hubungan penguasaan dan pemilikan (tenurial). 
Kewenangan dalam hak atas tanah itu meliputi: kewenangan pemilikan bagi hak atas tanah yang tidak memiliki jangka waktu (Hak Milik) dan kewenangan penguasaan untuk hak atas tanah dengan jangka waktu sementara (HGU, HGB, HP). Sebagaimana dikemukakan di atas, di dalam hak atas tanah itu, terkandung beberapa kewenangan seperti kewenangan menggunakan, mengalihkan, dan mengagunkan tanah yang dimilikinya (Pasal 4, 16, 20-45 UUPA). Oleh karena UUPA dibangun berdasarkan konsepsi, asas, lembaga, dan sistem pengaturan Hukum Adat, maka hakikat hak atas tanah, termasuk cara terjadinya hak atas tanah berdasarkan UUPA banyak mengikuti logika Hukum Adat (Boedi Harsono 2003, 229). Berdasarkan ketentuan Hukum Adat, hak atas tanah lahir karena proses individualisasi hak ulayat sebagai hak komunal.

Herman Soesangobeng mengatakan bahwa atas dasar hubungan ulayat maka dimungkinkan timbulnya hak-hak atas tanah. Hak-hak itu dilahirkan berdasarkan proses hubungan penguasaan nyata, utamanya oleh perorangan dan keluarga sebagai pemegang hak. Pertumbuhan hak atas tanah itu diawali dari pemilihan lahan berdasarkan Hak Wenang Pilih. Kemudian setelah pemberitahuan kepada kepala masyarakat dan pemasangan tandatanda larangan maka lahirlah Hak Terdahulu. Selanjutnya, setelah membuka hutan dan lahannya diolah serta digarap maka lahir Hak Menikmati. Baru setelah Hak Menikmati berlangsung cukup lama dan penggarapan lahan dilakukan secara terus menerus maka ia berubah menjadi Hak Pakai. Akhirnya, setelah penguasaan dan pemakaian itu berlangsung sangat lama sehingga terjadi pewarisan kepada generasi berikutnya, maka Hak Pakai pun berubah menjadi Hak Milik. Proses lahirnya hak atas tanah ini menurut Herman Soesangobeng, bila disederhanakan akan tampak sebagaimana pada ragaan 2 (Herman Soesangobeng 1998, 4).
Ragaan 2. Proses Lahirnya Hak Atas Tanah dari Tanah Ulayat

\begin{tabular}{|c|l|l|}
\hline NO. & \multicolumn{1}{|c|}{ T A H A P A N } & \multicolumn{1}{|c|}{ JENIS HAK } \\
\hline 1. & Pencarian dan pemilihan lahan & Hak Wenang Pilih \\
\hline 2. & $\begin{array}{l}\text { Pemberitahuan kepada kepala } \\
\text { masyarakat dan pemberian tanda } \\
\text { larangan atas tanah }\end{array}$ & Hak Terdahulu \\
\hline 3. & Membuka dan Mengolah Tanah & Hak Menikmati \\
\hline 4. & $\begin{array}{l}\text { Pengolahan tetap secara terus } \\
\text { menerus }\end{array}$ & Hak Pakai \\
\hline 5. & Mewariskan Tanah & Hak Milik \\
\hline
\end{tabular}

Menarik untuk mencermati praktik administrasi pertanahan mengenai berakhirnya hak atas tanah yang bersifat terbatas jangka waktunya, seperti Hak Guna Usaha (HGU) dan Hak Guna Bangunan (HGB) di atas tanah negara. Sebab, UUPA dan PP No. 40 Tahun 1996 menyatakan jika jangka waktu hak atas tanah yang terbatas itu berakhir, maka status tanahnya menjadi tanah negara. Namun, praktik administrasi pertanahan selama ini menunjukkan bahwa kepada bekas pemegang HGU tetap yang disebut oleh birokrasi pertanahan sebagai "hak prioritas" atau “hak keperdataan”. Pendirian semacam ini tampak jelas pada Surat Kepala BPN No. 540-1434-DI tanggal 22 Februari 2006, yang menyatakan bahwa meskipun HGU sudah berakhir jangka waktunya berstatus sebagai tanah yang langsung dikuasai negara, namun tidak dengan sendirinya menghapuskan aset dari bekas pemegang hak (dalam hal ini PTPN II), termasuk perbuatanperbuatan hukum oleh PTPN II terhadap tanah tersebut. Demikian pula, dalam praktik pelaksanaan program pembaruan agraria selama ini, setiap tanah negara bekas HGU yang akan dijadikan sebagai objek kegiatan pembaruan agraria, maka terlebih dahulu dipersyaratkan adanya pernyataan pelepasan (penguasaan) dari bekas pemegang hak (Perhatikan Surat Direktur Landreform - Kedeputian Bidang Pengaturan dan Penataan Pertanahan No. 43/S-LR/ VI/2010 tanggal 14 Januari 2010 yang menyatakan bahwa sesuai dengan Surat Keputusan Kepala BPN No. 25 Tahun 2002 tentang Pedoman Pelaksanaan Permohonan Penegasan Tanah Negara menjadi Obyek Pengaturan Penguasaan Tanah/Landreform, atas tanah-tanah negara bekas HGU tetap harus 
melampirkan surat pelepasan dari bekas pemegang hak). Julius Sembiring memaknai keharusan pelepasan bekas pemegang hak itu sebagai 'kebijakan pemutusan hubungan hukum bekas pemegang hak atas tanah' (Julius Sembiring 2012, 65).

Namun, praktik administrasi pertanahan di atas belum sepenuhnya diterima oleh pihak penegak hukum. Oleh karena, jajaran kepolisian dan kejaksaan misalnya, masih memandang bahwa pengalihan tanah Negara bekas HGU sebagai tindakan pidana korupsi, karena dipandang mengambil keuntungan dari pengalihan tanah negara kepada pihak lain (Oloan Sitorus 2008, 4). Dengan demikian, terdapat perbedaan persepsi terhadap status tanah negara bekas HGU yang berakhir jangka waktunya.

Menurut A. Sustiyadi, sampai saat ini persepsi di antara pejabat mengenai pengertian tanah negara sesungguhnya tidak ada persoalan, namun 'kedalaman' pengertian tersebut masih diwarnai oleh perbedaan pendapat antar para pejabat, yang secara sederhana dapat dibagi ke dalam 2 (dua) golongan. Pertama, pendapat yang menyatakan bahwa isi dari tanah negara harus dimengerti dalam konteksnya dengan Pasal 4 ayat (2) UUPA yang menyatakan bahwa hak atas tanah adalah hak yang memberikan wewenang untuk mempergunakan tanah yang bersangkutan, termasuk pula tubuh bumi dan air serta ruang yang ada di atasnya, sepanjang berhubungan langsung dengan penggunaannya. Konsekuensinya, jika hak atas tanah tersebut berhenti karena sesuatu perbuatan atau peristiwa hukum tertentu, maka berhenti/habis pula kewenangan untuk menggunakannya. Pemikiran yang demikian itu yang antara lain melandasi PP No. 40 Tahun 1996. Kedua, terhadap pemikiran bahwa kedalaman isi tanah negara tidaklah sejauh sebagaimana dimaksud dalam pendapat pertama di atas. Hal itu dapat diverifikasikan pada praktik-praktik di kalangan masyarakat dewasa ini. Sesuatu hak atas tanah, HGB misalnya, yang telah habis masa berlakunya dan kembali menjadi tanah negara ternyata masih dapat dijual (baca "dijual", tafsir penulis) kepada pihak lain oleh bekas pemiliknya tanpa suatu kesulitan, bahkan kelak, oleh instansi BPN sendiri di daerah, kenyataan sedemikian itu dijadikan alasan hukum untuk pemberian hak kepada pembelinya, sekiranya yang bersangkutan mengajukan permohonan hak. Dengan perkataan lain, pendapat kedua ini mengajukan suatu tesis bahwa hubungan subyek hukum dengan tanah pada hakikatnya berdimensi 2 (dua), yaitu berwujud: (a) hak atas tanah dan (b) pemilikan/penguasaan tanah (Sustiyadi 1997, 15-17).

Penulis berpendapat bahwa 2 (dua) dimensi hubungan subyek dengan tanah menurut pandangan A. Sustiyadi di atas, bukanlah sesuatu yang bersifat paralel, melainkan bersifat kontinum. Oleh karena setiap hak atas tanah lahir di atas hubungan hukum yang sudah terbangun terlebih dahulu. Hubungan hukum terdahulu itulah yang dalam praktik administrasi pertanahan disebut sebagai alas-hak. Dalam pemahaman yang seperti ini, maka ketika hak atas tanah yang berjangka waktu sementara (HGU, HGB, HP) berakhir jangka waktunya, maka "hak keperdataan", atau "hak prioritas" dari bekas pemegang hak belum tentu berakhir serta merta. Penulis berpendapat bahwa "hak prioritas" ini lahir dari kewajiban hukum si bekas pemegang hak, yang secara hukum wajib menjaga tanah bekas hak yang dipunyainya sebelumnya. Hukum mewajibkan kewajiban bekas pemegang hak untuk menjaga tanah tersebut, agar dapat dihindari kemungkinan terjadinya anarkhisme ataupun okupasi tanah yang tidak berdasarkan hukum. Dalam pada itulah, maka ketika tanah negara bekas tanah hak, akan diberikan kepada pihak lain, maka pihak lain yang akan menerima hak tersebut harus melakukan penyelesaian terhadap bekas pemegang hak.

Penyelesaian terhadap bekas pemegang hak ini dalam Peraturan Menteri Negara Agraria/Kepala BPN No. 9 Tahun 1999, dalam hal ini Pasal 29 (untuk HGU), Pasal 46 (untuk HGB), dan Pasal 63 (untuk $\mathrm{HP}$ ), disebut sebagai penggantian (bagi penerima 
hakyang baru bukan dalam rangka pengadaan tanah untuk kepentingan umum) atau ganti kerugian (bagi Pemerintah atau Pemerintah Daerah dalam rangka pengadaan tanah untuk kepentingan umum. Namun, perlu diingat bahwa penyelesaian berupa pemberian penggantian atau ganti-kerugian itu hanya dapat dilakukan ketika bekas pemegang hak tidak menjadikan tanah bekas haknya itu sebagai tanah terlantar.

Penggantian atau ganti kerugian kiranya juga tidak patut diberikan tanah negara yang terjadi karena pelanggaran terhadap prinsip nasionalitas dalam UUPA, seperti orang asing yang melakukan penyelundupan hukum terhadap Pasal 26 ayat (2) UUPA. Sebagaimana diketahui, hukuman bagi para pihak yang melakukan penyimpangan terhadap Pasal 26 ayat (2) tersebut adalah: 'perbuatan pemindahan hak itu batal karena hukum dan tanahnya jatuh pada negara'. Pertanyaannya, apakah bekas pemegang hak, dalam hal ini si orang asing, masih layak mendapat penggantian atau gantikerugian atas tanah negara bekas tanah hak-nya tersebut, jika tanah tersebut akan diberikan kepada penerima hak yang baru atau diambil oleh Pemerintah atau Pemerintah Daerah melalui pengadaan tanah untuk kepentingan umum?

Kalau dicermati kuatnya prinsip nasionalitas dalam menjiwai UUPA, maka makna 'tanah jatuh pada negara' berarti secara hukum status tanah tersebut menjadi 'tanah yang langsung dikuasai oleh negara' atau dalam konsep lama disebut sebagai vrij lands domein, sehingga kalau masih ada orang asing yang mendudukinya, dipandang sebagai menduduki tanah negara secara ilegal, yang menurut UU No. ${ }_{11}$ Prp. Tahun 1960 merupakan perbuatan yang dilarang dan diancam dengan hukum pidana (Pasal 2 dan 6). Perjanjian pinjam nama (nominee agreement) yang digunakan untuk menyiasati atau menyimpangi Pasal 26 ayat (2) UUPA di atas merupakan perbuatan yang secara tidak langsung adalah perbuatan yang melanggar prinsip nasionalitas yang dijunjung tinggi oleh UUPA. Ketentuan
Pasal 26 ayat (2) UUPA akan semakin memungkinkan untuk ditegakkan jika ada norma hukum yang secara tegas menyatakan bahwa si kedok dapat dikriminalisasi, oleh karena telah memungkinkan terjadinya perjanjian pinjam nama. Perjanjian pinjam nama itu mengakibatkan berbagai dampak ikutan lainnya yang dapat merugikan negara, seperti tidak samanya data formal dalam catatan otoritas pertanahan dengan data kepemilikan tanah yang sebenarnya.

Oleh karena itu, hendaknya RUU Pertanahan yang sedang disusun kemudian mengatur larangan pihak-pihak tertentu menjadi kedok dalam suatu perbuatan pemindahan hak atas tanah. Oleh karena, larangan yang berimplikasi pada dimungkinkannya pemidanaan seseorang itu secara teori perundangundangan hanya bisa menjadi materi-muatan UU (Oloan Sitorus 2012, 80).

Aspek hukum tanah negara sebagai akibat pelanggaran Pasal 26 ayat (2) UUPA sesungguhnya berbeda dengan aspek hukum tanah negara bekas tanah hak. Kalau dalam praktik penyelenggaraan pertanahan, tanah negara bekas tanah hak yang dikuasai oleh bekas pemegang hak memiliki "hak prioritas" untuk mengajukan permohonan hak atas tanah negara tersebut. Oleh karena itu, penguasaan pihak bekas pemegang hak itu dipandang sebagai penguasaan fisik yang diberi tanggungjawab hukum untuk menjadi "penjaga tanah Negara yang baik", sebelum tanah negara itu kemudian diberikan kepada pihak yang berhak atau berkepentingan. Sementara, tanah Negara yang terjadi karena pelanggaran Pasal 26 ayat (2) UUPA seyogianyalah dipandang sebagai hukuman terhadap pihak yang secara sengaja melanggar ketentuan larangan pemindahan hak kepada orang asing. Dalam pada itu, kalau pihak yang melanggar ketentuan Pasal 26 ayat (2) UUPA itu masih menguasai tanah Negara tersebut, maka penguasaan itu dapat dikategorikan sebagai penguasaan ilegal. Penegasan bahwa penguasaan tanah negara sebagai akibat pelanggaran Pasal 26 ayat (2) UUPA sebagai penguasaan ilegal, 
juga seyogianyalah diatur di dalam RUU Pertanahan yang sedang disusun sekarang ini.

\section{Ijin Usaha Pertambangan sebagai bentuk hubungan hukum}

Penataan hubungan hukum antara subjek hukum dengan sumber daya agraria pada dasarnya telah diatur secara sederhana dalam UUPA. Hubungan antara orang dengan tanah diakomodasi dengan 'hak', sedangkan hubungan antara orang dengan sumberdaya agraria lainnya yang non tanah diakomodasi dengan ijin (Pasal 4 jo Pasal 8 UUPA). Secara sederhana dapat dikatakan bahwa hubungan hukum dengan tanah lebih kuat daripada hubungan hukum dengan sumberdaya agraria lainnya, oleh karena hak atas tanah hanya dapat diberikan terhadap terhadap suatu subjek hukum jika sebelumnya telah ada alas hak yang mendasarinya; sedangkan ijin dapat diberikan kepada suatu subjek hukum meskipun sebelumnya belum memiliki alashak. Selain itu, pada penetapan hubungan hukum berupa hak atas tanah dalam skala besar bahkan harus didahului ijin lokasi, yakni ijin untuk memastikan bahwa tanah yang akan diperoleh telah sesuai dengan tata ruang. Mencermati karakter hukum yang terdapat pada hubungan hukum dengan tanah dan bahan tambang penting dilakukan ketika kenyataan menunjukkan bahwa pemberian kedua hubungan hukum itu dapat terjadi di atas ruang atau di lokasi yang sama.

Sebagaimana ditentukan dalam Pasal 4 dan 8 UUPA di atas bahwa hubungan hukum dengan tanah disebut hak atas tanah (permukaan bumi), sedangkan hubungan hukum dalam pemanfaatan bahan tambang dalam tubuh bumi disebut ijin, yakni Ijin Usaha Pertambangan (IUP). Dalam implementasinya, risiko terjadinya "konflik" antara hak atas tanah dengan IUP akan potensial terjadi. Oleh karena, dalam proses pemberian IUP dikenal konsep Wilayah Pertambangan (WP) sebagai landasan bagi penetapan kegiatan pertambangan. WP ditetapkan oleh Pemerintah setelah berkoordinasi dengan
Pemerintah Daerah (Pemda) dan berkonsultasi dengan Dewan Perwakilan Rakyat Republik Indonesia (DPR RI) (Pasal 9 ayat (2)).

WP yang ditujukan untuk usaha pertambangan disebut Wilayah Usaha Pertambangan (WUP). WUP ditetapkan oleh Pemerintah setelah berkoordinasi dengan pemerintah daerah dan disampaikan secara tertulis kepada Dewan Perwakilan Rakyat Republik Indonesia (Pasal 14 ayat (1)). Selanjutnya, dikenal pula konsep Wilayah Izin Usaha Pertambangan, yang selanjutnya disebut WIUP, yaitu wilayah yang diberikan kepada pemegang IUP (Pasal 1 butir 31). Luas dan batas WIUP mineral logam dan batubara ditetapkan oleh Pemerintah berkoordinasi dengan pemerintah daerah berdasarkan kriteria yang dimiliki oleh Pemerintah (Pasal 17).

Di atas WIUP itulah diberikan IUP. IUP diberikan oleh bupati/walikota apabila WIUP berada dalam satu wilayah kabupaten/kota. IUP diberikan oleh gubernur apabila WIUP berada pada lintas wilayah kabupaten/kota dalam 1 (satu) provinsi setelah mendapatkan rekomendasi dari bupati/walikota setempat sesuai dengan ketentuan peraturan perundang-undangan. IUP diberikan Menteri apabila WIUP berada pada lintas wilayah provinsi setelah mendapatkan rekomendasi dari gubernur dan bupati/walikota setempat sesuai dengan ketentuan peraturan perundang-undangan (Pasal 37).

Berdasarkan konsep WP dan WIUP di atas, maka konflik antara hak atas tanah sebagai hubungan hukum dengan tanah (di permukaan bumi) dengan IUP sebagai hubungan hukum dengan bahan tambang (di tubuh bumi) akan potensial terjadi. Bahkan dapat dikatakan sebagai sesuatuyang bersifat alami karena hampir semua bahan galian tambang terdapat di bawah tanah yang di atasnya ditumbuhi hutan, sehingga tidak bisa dihindari tetapi harus dihadapi dengan kemampuan membuat regulasi yang tumpang tindih atau harmonis (Abrar Saleng, 2004: 185). Sebagaimana dikemukakan di atas, secara 
teoretis hubungan hukum dengan tanah lebih kuat daripada ijin. Namun, perkembangan aturan hukum agraria tampaknya tidak sepenuhnya berjalan seperti pemahaman di atas. Ketika hak atas tanah "berkonflik" dengan ijin usaha tambang, maka hak atas tanah harus "dikalahkan". Hal itu tampak dari ketentuan UU No. 1 Tahun 1967 tentang Ketentuanketentuan Pokok Pertambangan yang intinya mengatakan bahwa apabila ijin kuasa pertambangan atas suatu daerah atau wilayah telah diperoleh (suatu perusahaan), maka kepada yang berhak atas tanah 'diwajibkan memperbolehkan pekerjaaan pemegang kuasa pertambangan atas tanah yang bersangkutan atas dasar mufakat' (Pasal 26). Pemegang kuasa pertambangan diwajibkan mengganti kerugian akibat dari usahanya pada segala sesuatu yang berada di atas tanah kepada yang berhak atas tanah di dalam lingkungan daerah kuasa pertambangan maupun di luarnya (Pasal 25). Inpres No. 1 Tahun 1976 secara tegas menyatakan: "bila pertindihan penetapan/ penggunaan tanah tidak dapat dicegah, maka hak prioritas pertambangan harus diutamakan". Berarti, di dalam UU No. 11 Tahun 1967 ini, tidak ada pilihan pemegang hak atas tanah selain, menerima kehadiran pemegang ijin usaha pertambangan. Bahkan, pemegang hak atas tanah yang merintangi atau mengganggu usaha pertambangan yang sah diancam dengan pidana.

UU Minerba Nomor 4 Tahun 1999 tentang Pertambangan Mineral dan Batubara (selanjutnya disebut Minerba), tampaknya juga mengambil sikap yang sama. Pasal 37 dan Pasal 134 s/d 138 UU Minerba juga menyatakan bahwa perusahaan pertambangan harus menyelesaikannya terlebih dulu dengan pemegang hak atas tanah pada daerah yang akan dikerjakan, yang pelaksanaannya dapat dilakukan bertahap sesuai kebutuhan. Lebih lanjut, PP 23 Tahun 2010 Pasal 100 ayat (1) dan (2) mengatur penyelesaian kompensasi melalui sewa menyewa, jual beli, atau pinjam pakai. Oleh karena itu, penyelesaian di luar skenario tersebut dipandang tidak sesuai dengan peraturan perundangan.
Menarik untuk mencermati, mengapa posisi hak atas tanah sebagai hubungan hukum penguasaan dan pemilikan tanah selalu "dikalahkan" oleh Ijin Usaha Pertambangan (IUP), sebagai hubungan hukum pemanfaatan sumberdaya agraria di tubuh bumi? Pertimbangan-pertimbangan apakah yang membuat posisi pemegang IUP selalu memenangkan "konflik tumpang tindih" antara hak atas tanah dengan IUP? Padahal, dalam makna terminologiyuridis, hubungan hukum dengan tanah terkesan lebih kuat daripada hubungan hukum dengan bahan tambang dalam tubuh bumi. Bukankah, akan timbul berbagai komplikasi hukum, sekiranya dalam praktiknya setiap IUP diposisikan selalu mengalahkan hak atas tanah, seperti: terpinggirkannya pemegang hak atas tanah dari setiap kegiatan penambangan, meskipun pemegang IUP adalah badan hukum privat yang kedudukannya sama dengan orang (pribadi hukum) (Perhatikan http:// cetak.kompas.com /read/2013/o1/17/ 04154754/ izin.tambangmeningkat. jelang. pemilu, Politik Ekologi - Izin Tambang Meningkat Jelang Pemilu, Diunduh 25 Januari 2013).

Secara teoritis, derajat hubungan hukum yang terdapat pada ijin (vergunning), tidak sekuat sebagaimana yang terdapat pada hak, dalam hal ini hak atas tanah. Bagir Manan, sebagaimana dikutip Adrian Sutedi, menyebutkan bahwa izin dalam arti luas berarti suatu persetujuan dari penguasa berdasarkan peraturan perundang-undangan untuk memperbolehkan melakukan tindakan atau perbuatan tertentu yang secara umum dilarang (Ardian Sutedi 2010, 170). N.M. Spelt dan J.B.J.M ten Berge membagi pengertian izin dalam arti luas dan sempit. Izin dalam arti sempit disebut izin (izin saja) sedangkan istilah izin dalam arti luas disebut perizinan yaitu izin yang merupakan salah satu instrumen yang paling banyak digunakan dalam hukum administrasi (Helmi 2012, 27). Izin ialah suatu persetujuan dari penguasa berdasarkan undangundang atau peraturan pemerintah untuk dalam keadaan tertentu menyimpang dari ketentuan- 
ketentuan larangan peraturan perundang-undangan. Dengan memberi izin, penguasa memperkenankan orang (termasuk badan hukum) yang memohonnya untuk melakukan tindakantindakan tertentu yang sebenarnya dilarang (Helmi 2012, 170-171).

Secara sekilas pengertian izin dengan konsesi tidak berbeda. Masing-masing berisi perkenan bagi seseorang untuk melakukan suatu perbuatan atau pekerjaan tertentu. Dalam pengertian sehari-hari, kedua istilah itu digunakan secara sama. Menurut E. Utrecht, perbedaan antara izin dengan konsesi itu adalah suatu perbedaan nisbi (relatif) saja. Pada hakikatnya antara izin dengan konsesi itu tidak ada suatu perbedaan yuridis. Sebagai contoh, izin untuk mendapatkan batubara menurut suatu rencana yang sederhana saja dan akan diadakan atas ongkos sendiri tidak dapat disebut konsesi. Akan tetapi, izin yang diberikan menurut Undang-undang Tambang Indonesia untuk mendapatkan batubara adalah suatu konsesi, karena izin tersebut mengenai suatu pekerjaan yang besar dan pekerjaan yang besar itu akan membawa manfaat bagi umum. Jadi konsesi itu suatu izin pula, tetapi izin mengenai hal-hal yang penting bagi umum (Ardian Sutedi, 2010, 171).

Terminologi yuridis bagi hubungan hukum pengambilan kekayaan tambang (di dalam tubuh bumi) sejak Indonesia merdeka berubah sesuai hubungan negara dengan kekayaan alam yang terkandung di wilayah Indonesia. Pasal 8 UUPA, menggunakan istilah 'kuasa pertambangan'. Istilah 'kuasa pertambangan' untuk pertama kali diintroduksi untuk menggantikan 'konsesi' dalam aturan keagrariaan nasional. Dalam terminologi 'kuasa pertambangan' terkandung perubahan paradigma hubungan hukum antara pihak yang mengambil kekayaan alam dengan negara sebagai pemegang hak menguasai negara atas kekayaan alam. Di dalam Indische Mijn Wet (IMW) tahun 1899 dinyatakan bahwa hubungan hukum antara penambang dengan kekayaan alam dikontruksikan dalam sistem konsesi. Dengan sistem konsesi, perusahaan pertambangan tidak hanya diberikan "kuasa pertambangan", tetapi diberikan pula 'hak menguasai atas tanah'. Hak konsesi yang terlalu luas ini akhirnya tidak lagi digunakan dalam UU No. 37 Prp Tahun 1960 tentang Pertambangan.

Tegasnya, UU 37 Prp Tahun 1960 itu pun akhirnya secara resmi menggunakan istilah "kuasa pertambangan' sebagai istilah yuridis bagi hubungan hukum antara pihak yang melakukan penambangan dengan bahan galian tambang. Namun, semangat dan jiwa UUPA dan UU No. 37 Prp Tahun 1960 yang nasionalistik itu tidak dapat dijabarkan lebih komprehensif, oleh karena kenyataan sejarah yang melahirkan Orde Baru sebagai babakan pemerintahan yang sudah mempunyai politik pembangunan yang berbeda dengan Orde Lama. Kehadiran UU No. 11 Tahun 1967 tentang Ketentuanketentuan Pokok Pertambangan menggantikan UU No. 37 Prp Tahun 1960 meneguhkan perbedaan politik pembangunan di bidang pertambangan, yang secara tegas di dalam Konsiderans UU No. 11 Tahun 1967 itu dinyatakan bahwa keberadaannya adalah untuk 'mempercepat terlaksananya pembangunan ekonomi nasional' dan dalam rangka 'memperkembangkan usaha-usaha pertambangan di Indonesia'.

Meskipun hubungan hukum pengambilan kekayaan tambang disebut 'kuasa pertambangan', namun hakikatnya secara hukum adalah ijin, yakni persetujuan penguasa, dalam hal ini otoritas pertambangan, untuk mengambil kekayaan alam yang terkandung di dalam tubuh bumi, berdasarkan UU Pertambangan. Terminologi ijin akhirnya secara eksplisit disebut dalam UU Minerba. Berdasarkan UU Minerba, Ijin Usaha Pertambangan (IUP) bukanlah pemilikan hak atas tanah (Pasal 138), tetapi izin untuk melaksanakan usaha pertambangan (Pasal 1 butir 7). Pasal 36 ayat (1) UU Minerba menyatakan bahwa IUP terdiri atas 2 (dua) tahap, yakni IUP Eksplorasi meliputi kegiatan penyelidikan umum, eksplorasi, dan studi kelayakan (vide Pasal 1 butir 8); dan IUP Operasi Produksi yang meliputi 
kegiatan konstruksi, penambangan, pengolahan dan pemurnian, serta pengangkutan dan penjualan (vide Pasal 1 butir 9). Menurut Budi Santoso, lingkup kegiatan dan implikasi dari kedua tahapan itu kadang-kadang tidak begitu dipahami oleh Pemerintah Daerah sehingga melakukan penilaian tidak proporsional terhadap IUP, seperti menuduh IUP tidak didayagunakan. Akibatnya, hal itu alasan bagi Pemerintah Daerah untuk menerbitkan IUP di atas lahan yang sudah IUP-nya. Inilah penyebab pertama mengapa terjadi IUP yang tumpang tindih (Perhatikan http://budisansblog.blogspot.com/2012/ o6/tumpang-tindih-lahan-siapa-yang-salah.html, Diunduh 25 Januari 2013).

Selain tumpang tindih IUP, penelitian juga menunjukkan adanya tumpang tindih antara Kuasa Pertambangan dengan hak atas tanah. Penelitian Wahbah HL di Kabupaten Tanah Bumbu Provinsi Kalimantan Selatan menunjukkan tumpang tindih antara Kuasa Pertambangan dengan hak atas tanah tersebut disebabkan oleh adanya masalah dalam proses pembebasan tanah dan pemberian ganti rugi, adanya kepemilikan tanah ganda, kegiatan usaha pertambangan berada di luar dari peta wilayah pertambangan pemegang kuasa pertambangan, dan tumpang tindih perizinan antara kuasa pertambangan dengan perizinan perkebunan. Beberapa upaya yang ditempuh oleh para pihak yaitu dengan cara musyawarah antara para pihak, upaya mediasi dengan bantuan mediator, dan melalui jalur pengadilan. Secara umum para pihak lebih memilih jalur non-litigasi dalam menyelesaikan masalahnya daripada melalui jalur litigasi (Wahbah HL 2009, 110115).

Penelitian Senthot Sudirman, dkk, menunjukkan bahwa di Provinsi Bangka Belitung terdapat kegamangan birokrasi pertanahan dalam pengaturan penguasaan dan pemilikan serta penggunaan dan pemanfaatan tanah pasca tambang timah. Sampai saat ini, terkesan adanya "kekosongan hukum" dalam pengaturan penguasaan dan pemilikan serta penggunaan dan pemanfaatan tanah pasca tambang tersebut. Meskipun dalam diskusi yang berkembang di internal otoritas pertanahan di Kanwil Provinsi Bangka Belitung, semua dapat menyepakati bahwa status tanah pasca tambang adalah tanah negara. Namun, belum ada sikap yang tegas dan tindakan konkrit yang dilakukan otoritas pertanahan yang dapat menunjukkan kepastian status tanah pasca tambang tersebut. Padahal, ada keinginan dari Pemerintah Daerah untuk mengelola dan mengatur peruntukan dan pemanfaatan tanah pasca tambang tersebut berbasiskan Hak Pengelolaan (Senthot Sudirman dkk 2012, 21-25). Ketidaktegasan sikap otoritas pertanahan terhadap status tanah pasca tambang ini mengakibatkan terganggunya pelayanan pertanahan di lokasi pasca tambang, seperti tertundanya legalisasi tanah pasca tambang meskipun secara faktual sudah menjadi permukiman yang kompak.

Oleh karena itu, kebijakan pertanahan pasca tambang kiranya juga mendesak untuk diformulasikan. Pengalaman Arie Yuriwin sebagai Kakanwil BPN Provinsi Bangka Belitung (Babel) menunjukkan bahwa tanah pasca tambang, ini perlu mendapatkan pemikiran serius karena disinyalir memang terjadi kekosongan peraturan tanah pasca tambang (Wawancara dengan Kakanwil BPN, 30 Mei 2012). Arie Yuriwin menyarankan, harus ada kebijakan tentang nasib tanah pasca tambang. Berbagai fakta menunjukkan pentingnya segera mengintroduksi kebijakan tanah pasca tambang. Pertama, otoritas pertanahan belum berani menerbitkan sertipikat tanah di atas tanah Kuasa Pertambangan (KP), meskipun usaha tambang telah selesai dan reklamasi sudah dilakukan. Bahkan, ada indikasi menjadikan reklamasi sebagai upaya untuk menumbuhkan hubungan hukum awal (atau semacam alas hak), agar pemegang KP atau IUP dapat memperoleh tanah pasca tambang tersebut. Ditegaskan, sesungguhnya reklamasi tidak menjadikan pemegang KU/IUP sebagai pemegang "hak prioritas" untuk mengajukan permohonan hak atas tanah bekas tambang. Tanah pasca tambang berstatus sebagai tanah Negara yang 
bebas dari penguasaan pihak mana pun, sehingga menjadi domein Kementerian Agraria dan Tata ruang/BPN (Kementerian ATR/BPN). Kedua, ada juga fakta bahwa pemegang KP/IUP yang sudah selesai melakukan usaha tambang, tetapi KP/IUPnya masih hidup, melakukan tindakan penggunaan tanah untuk usaha perkebunan. Kiranya hal ini tidak dapat dibenarkan secara hukum. Oleh karena, KP/ IUP bukanlah hak atas tanah, sehingga tidak dapat digunakan sebagai alasan/kewenangan untuk menggunakan tanah tersebut.

Dalam pada itulah, maka di dalam RUU Pertanahan yang sedang disusun, kiranya penting untuk mengkonfirmasi bahwa status tanah pasca tambang adalah tanah negara yang langsung menjadi domein Kementerian ATR/BPN. Dengan catatan, bahwa tanah di atas kegiatan pasca tambang itu memang belum dibebaskan oleh pemegang KP/IUP sebelum melakukan usaha tambang.

\section{Penutup}

Hubungan hukum dengan tanah dan sumberdaya agraria lainnya penting untuk ditata kembali dengan kembali pada konsep dasar hak dan ijin sebagai salah satu bentuk kewenangan HMN atas sumberdaya agraria. Di dalam RUU Pertanahan kiranya penting mengkonfirmasi pengaturan bahwa semua hubungan hukum dengan tanah mulai dari penggarapan (okupasi) melalui ijin garap (seperti Surat Keterangan Tanah dan/atau Akta Pelepasan Hak dan Ganti Kerugian), menuju pada possession (pemunyaan), dan legalisasi hak menjadi pemilikan (ownership) melalui penetapan pemerintah, seyogianyalah menjadi domein Kementerian ATR/ BPN. Sekiranya, gagasan mendasar ini belum mampu diwujudkan, setidaknya perlu dilakukan Revisi Peraturan Pemerintah yang mengatur penguasaan tanah Negara. Harus ditegaskan bahwa penguasaan tanah Negara berada pada Kementerian ATR/BPN. Agar penataan ini dapat dilakukan secara tuntas sampai ke tingkat kecamatan dan desa, maka perlu ada perwakilan ATR/BPN sampai di tingkat
Kecamatan dan petugas ATR/BPN sampai ke tingkat Desa. Konfirmasi lain yang dibutuhkan dalam RUU Pertanahan adalah status tanah di atas IUP atau Kehutanan. Ranah hukum IUP berada pada tubuh bumi, bukan permukaan bumi, sehingga IUP tidak boleh dijadikan sebagai dasar kewenangan untuk melakukan usaha-usaha pertanian atau perkebunan di atas permukaan tanah yang berada di atas IUP. Selanjutnya, setelah IUP berakhir, maka kewajiban reklamasi lokasi tambang juga tidak dapat dijadikan sebagai entry point untuk membangun semacam alas hak untuk diprioritaskan mengajukan permohonan atas tanah. Reklamasi adalah kewajiban hukum yang harus dijalankan oleh pelaku usaha pertambangan.

\section{Daftar Pustaka}

Hasan, Djuhaendah, 1996, Lembaga jaminan kebendaan bagi tanah dan benda lain yang melekat pada tanah dalam konsepsi penerapan asas pemisahan horisontal, PT.Citra Aditya Bakti, Bandung.

Harsono, Boedi, 2003, Hukum agraria Indonesia sejarah pembentukan Undang-undang pokok agraria, isi dan pelaksanaannya, Jilid I, Cetakan Kesembilan (Edisi Revisi), Penerbit Djambatan, Jakarta.

Helmi, 2012, Hukum perizinan lingkungan hidup, Penerbit Sinar Grafika, Jakarta.

Herman Soesangobeng, Herman, 1998, Filosofi Adat dalam UUPA, Makalah dipresentasikan dalam Sarasehan Nasional "Peningkatan Akses Rakyat Terhadap Sumberdaya Tanah”, Diselenggarakan oleh Kantor Menteri Negara Agraria/BPN bekerjasama dengan ASPPAT, tanggal 12 Oktober 1998, di Jakarta.

Sustiyadi, 1997, Beberapa Bahan Pemikiran Penyusunan Rencana Peraturan Pemerintah tentang Pengelolaan Tanah Negara, Penerbit Badan Pertanahan Nasional.

HL, Wahbah, 2009, Tumpang tindih antara tanah kuasa pertambangan dengan hak atas tanah, Tesis Program Magister Kenotariatan UGM, Yogyakarta. 
Saleng, Abrar, 2004, Hukum pertambangan. UII Press, Yogyakarta.

Sembiring, Julius, 2012, Tanah negara, Penerbit STPN Press, Yogyakarta.

Sudirman, Senthot, dkk, 2012, Kebijakan, konflik, dan perjuangan agraria Indonesia awal abad 21 (Hasil Penelitian Sistematis STPN, 2012), STPN Press, Yogyakarta.

Sitorus, Oloan, 2008, 'Aspek Hukum Tanah Negara Bekas Hak Guna Usaha Perkebunan di Provinsi Sumatera Utara', Jurnal Bhumi STPN, No. 24 Tahun 8, Desember 2008.

Sitorus, Oloan, dkk, 2012, Penguasaan Tanah Melalui Penyelundupan Hukum Oleh Orang Asing di Pulau Lombok Provinsi Nusa Tenggara Barat (Studi di Kabupaten Lombok Barat, Lombok Utara, Lombok Tengah, dan Kota Mataram), Laporan Penelitian Strategis, Dosen STPN.
Sutedi, Ardian, 2010, Hukum perizinan dalam sektor pelayanan publik, Penerbit Sinar Grafika, Jakarta.

http://cetak.kompas.com/read/2013/o1/17/ o 4154754 / i z i n . t a m b a n g . meningkat.jelang.pemilu, Politik Ekologi Izin Tambang Meningkat Jelang Pemilu, dilihat pada 25 Januari 2013.

htt p: / / www.theglobalreview.com / content_detail.php?lang=id\&id=9057\& type=10\#.UQHaufIU-NY, Potensi Tambang Sulawesi Tenggara dalam Kepungan Investor, dilihat pada 25 Januari 2013.

http://budisansblog.blogspot.com/2012/o6/ tumpang-tindih-lahan-siapa-yangsalah.html, dilihat pada 25 Januari 2013. 